\title{
Lições para tornar a terra habitável
}

\section{Lessons to make the earth habitable}

\section{Lecciones para hacer la tierra habitable}

Tadeu de Oliveira Silva

Alexsandro Galeno Araújo Dantas Universidade Federal do Rio Grande do Norte (Brasil)

MORIN, Edgar; SLOTERDIJK, Peter. Tornar a terra habitável. Tradução Edgard de Assis Carvalho e Fagner França. Natal: EDUFRN, 2021.

O livro Tornar a Terra habitável apresenta o diálogo entre o sociólogo, antropólogo e filósofo francês Edgar Morin e o filósofo alemão Peter Sloterdijk, debate traduzido por Edgard de Assis Carvalho e Fagner França, publicado pela EDUFRN em 2021, em formato eletrônico e impresso. A obra conta com 91 páginas, um texto extraído das conversas entre os autores em debates nas sessões do Collegium International IInternational Ethical, Scientific and Political Collegium), em 2011.

A estrutura do livro apresenta o capítulo de abertura com o título de Coimunidades, escrito por Alex Galeno, Fagner França e Lucas Fortunato, professores e pesquisadores do Programa de Pós-graduação em Ciências Sociais da Universidade Federal do Rio Grande do Norte. Na sequência, o capítulo Diálogo entre Edgar Morin e Peter Sloterdijk apresenta o debate entre os autores e, encerrando a obra, o Posfácio escrito por Edgard de Assis Carvalho, professor e pesquisador da Pontifícia Universidade Católica de São Paulo.

Em Comunidades, está presente uma síntese de Tornar a Terra habitável, uma compilação dos conceitos trabalhados no decorrer do texto, entre eles, a coimunidade como um imperativo para a sobrevivência comum. Destaca-se a importância do debate entre Sloterdijk e Morin para os dias atuais, momento em que a civilização moderna vive uma "policrise", de acordo com o autor francês. Crise que se arrasta pelo menos desde o atentado contra o World Trade Center, em 2001, atrelado ao contexto da pandemia da Covid-19 e suas implicações para a humanidade a partir de 2020. 
O capítulo Diálogo entre Edgar Morin e Peter Sloterdijk começa com a apresentação da imunologia geral, proposta pelo filósofo alemão, fortalecendo a solidariedade, a convivência e a empatia entre os indivíduos. Sloterdijk busca as características que estabelecem uma retórica humanitária na história da humanidade, que o autor denomina como universalismo "familialista".

filósofo trabalha com o conceito de "megalopsiquia" de Aristóteles. indivíduo "megalopsíquico" está sempre pronto para aceitar os outros como membros da família. Tomando esse modelo, devemos olhar para todos os estrangeiros da humanidade como membros de uma mesma família, uma mesma comunidade com o mesmo destino.

A "megalopsiquia" exige a retomada dos conceitos de responsabilidade e solidariedade preconizados por Sloterdijk. Precisamos enfrentar os efeitos de nossas ações como, por exemplo, o descarte do lixo que produzimos e invade as praias. A ética da hospitalidade precisa tornar-se uma ascese, exercício diário de respeito ao próximo e é importante o retorno da palavra "sabedoria" relacionada à vida comum, termo que foi excluído na modernidade.

De acordo com Morin, a sabedoria moderna deve manter um diálogo permanente entre a razão e a paixão, visto que uma vida totalmente racional seria delirante. Devemos desenvolver a parte do homo demens no homo sapiens, ter consciência sobre as doenças da razão e dos usos criminosos da racionalidade como a razão instrumental denominada por Theodor Adorno e Max Horkheimer.

A necessidade de reaprender a arte de viver é ressaltada por Peter Sloterdijk no discurso sobre a sabedoria, visando uma desintoxicação do ambiente psicológico da compulsão pela comparação, cotidiano que envenena os indivíduos. Comparar-se com alguém que vive melhor, tem mais coisas, mais poder contribui para o surgimento de doenças psicológicas, movimento que tende a crescer nos dias de hoje.

A ideia de imunologia proposta por Sloterdijk reforça a de interdependência de Morin, conceito que perpassa todos os estudos publicados do autor francês. $\bigcirc$ triplo sistema imunitário proposto pelo filósofo alemão (imunologias do corpo; jurídica e solidária; simbólica) se relaciona com a realidade trinitária da condição humana de Morin (sujeito, sociedade e espécie). A base ética dos sistemas imunitários precisa ser elaborada em uma ética interior (do 
sujeito), exterior (que diz respeito à sociedade) e anterior (voltada para a espécie humana).

Sobre a condição humana, o paradoxo da nossa situação atual, de acordo com Sloterdijk, é que o pior não aconteceu até o momento e, enquanto o pior não acontecer, a linguagem de prevenção pode parecer frágil. Para lidar com os dilemas e desafios do século XXI, precisamos abraçar novas possibilidades e acreditar nelas.

No decorrer do diálogo, além das ideias de reforma e de revolução, Morin lança a via da metamorfose. Para Sloterdijk essa substituição poderia ser considerada como a expressão semântica mais importante do século XXI. A metamorfose consiste em uma transformação radical, mas também em uma continuidade. É uma perspectiva dialógica que nos faz refletir sobre o que devemos conservar e o que devemos abandonar.

Sloterdijk destaca que é necessário um pensamento apocalíptico esclarecido contra a frivolidade e o otimismo tolo, caso contrário, a catástrofe é mais provável. É preciso proteger o mundo antes de pensarmos em mudá-lo, visto que pode não existir mundo para transformar.

Morin ressalta que o desenvolvimento é a imposição do esquema ocidental em culturas muito diversas, sem considerar suas riquezas e singularidades. Defende que o desenvolvimento deve ser ultrapassado pela ideia de simbiose de civilizações (Ocidente e Oriente, Norte e Sul). Para o autor, é melhor perguntarmos o que deve crescer e o que deve decrescer (por exemplo, a economia verde e os gastos militares, respectivamente) e indicar a possibilidade de a humanidade mudar de via.

Em uma via totalmente nova, não há modelos para imitar e não é necessário indicar as transformações necessárias, de acordo com o autor francês. Sloterdijk destaca a ênfase na linguagem da urgência, visto que o irreversível se faz presente em nossa vida contemporânea. Morin ressalta que é preciso que se tenha consciência sobre a urgência para que a linguagem da urgência seja compreendida e encerra o diálogo com um convite para que se inicie a transformação dos rumos da humanidade.

P Posfácio escrito por Edgard de Assis Carvalho reitera as ideias de Morin e Sloterdijk e analisa os conceitos de cada autor em relação ao cenário da pandemia do novo coronavírus (Covid-19), destacando a presença e a 
relevância da Ciência na busca por uma resolução do problema e seus vários desdobramentos na humanidade.

Obra que celebra o centenário de Morin, comemorado em 8 de julho de 2021, tornar a Terra habitável destaca pontos de encontro entre o pensamento dos consagrados autores sobre formas de transformação das condições da vida humana na Terra. O livro visa iluminar o debate sobre a crise civilizatória da humanidade, que também é uma crise ética, econômica, cultural, entre outras, e elaborar formas de lidar com esses males.

Uma mudança de consciência dos seres humanos é necessária e, para que ela seja feita, educadores e pesquisadores têm uma ação essencial nesse processo, assumindo o compromisso ético desse convite à transformação cognitiva em suas áreas de atuação, nas escolas e universidades.

A importância do pensamento científico no enfrentamento dos problemas da humanidade faz do livro uma indicação importante para diversas áreas do conhecimento, em particular, a área da educação, na tarefa de reaprender a arte de viver. Após mais de dez anos da realização do evento que uniu dois dos grandes nomes do pensamento mundial, a solidez das ideias persiste ao teste aplicado pelo tempo.

Tadeu de Oliveira Silva

Universidade Federal do Rio Grande do Norte (Brasil) Mestrando do Programa de Pós-Graduação em Ciências Sociais Marginália - Grupo de Estudos Transdisciplinares em Comunicação e Cultura

Orcid id: https:/ / orcid.org/0000-000 1-8272-0746 E-mail: tadeudeoliveira_@hotmail.com 
Prof. Dr. Alexsandro Galeno Araújo Dantas Universidade Federal do Rio Grande do Norte (Brasil) Coordenador do Programa de Pós-Graduação em Ciências Sociais Professor do Programa de Pós-Graduação em Estudos da Mídia Marginália - Grupo de Estudos Transdisciplinares em Comunicação e Cultura Orcid id: https:/ / orcid.org/0000-000 1-51 03-0339

E-mail: alexgalenno@gmail.com

Recebido 10 out. 2021 Aceito 27 out. 2021 